\title{
Kesuksesan Karier Subjektif sebagai Identitas Karier Karyawan
}

\author{
Success of Subjective Career As Employee Career Identity \\ Tri Muji Ingarianti ${ }^{1,2}$, Fajrianthi ${ }^{1}$, Achmad Chusairi ${ }^{1}$ \\ 1Program Doktoral Psikologi, Universitas Airlangga \\ ${ }^{2}$ Fakultas Psikologi, Universitas Muhammadiyah Malang
}

Disubmit 6 Februari 2019 Diterima 6 Mei 2020 Diterbitkan 22 Desember 2020

\begin{abstract}
Subjective career success continues to be seen as a major area of interest and exploration both in academia and practice. The modern career context emphasizes mobility and unpredictability. Therefore, the employees can no longer rely solely on organizations in order to achieve the career success. They have responsibility to managing their own careers and creating career options. The purpose of this paper is to review relevant literatures on subjective career success and develop a theoretical framework concerning about the concept and the definition of subjective career success, the factors that are associated with subjective career success, the impact of subjective career success, and the role of career identity to the subjective career success. Understanding the subjective career success is an important task for individuals and organizations.
\end{abstract}

Keywords: career identity; employees; organization; subjective career success

Abstrak. Kesuksesan karier subjektif dipandang sebagai bidang utama yang diminati dan eksplorasi, baik di bidang akademik maupun praktik. Konteks karier modern lebih menekankan pada mobilitas dan ketidakpastian. Oleh karena itu, karyawan tidak lagi hanya mengandalkan organisasi untuk mencapai kesuksesan kariernya. Mereka memiliki tanggung jawab untuk mengelola dan menciptakan pilihan-pilihan karier mereka sendiri. Memahami kesuksesan karier subjektif adalah tugas penting bagi individu dan organisasi. Tujuan dari tulisan ini adalah untuk melakukan telaah literatur yang relevan mengenai kesuksesan karier subjektif dan mengembangkan kerangka teoretis tentang konsep dan definisi kesuksesan karier subjektif, faktor-faktor yang berhubungan dengan kesuksesan karier subjektif, dampak dari kesuksesan karier subjektif dan peran identitas karier terhadap kesuksesan karier subjektif.

Kata kunci: identitas karier; karyawan; organisasi; kesuksesan karier subjektif

\section{Pengantar}

Perubahan yang terjadi pada sektor teknologi dan ekonomi memberikan dampak terhadap pekerjaan dan karier

\footnotetext{
${ }^{1}$ Korespondensi mengenai artikel ini dapat dilakukan melalui: Ingarianti2016@gmail.com
}

individu. Kontrak kerja organisasi dan karyawan yang berbasis kapitalisme dan menawarkan keamanan kerja seumur hidup telah mengalami kehancuran di Amerika Serikat pada tahun 1980-an dan di Eropa beberapa dekade kemudian (Hall, 1996). Singkatnya, tampak bahwa 
konsep kerja tradisional menjadi sama sekali tidak berfungsi. Terlihat bahwa karier di masa kini ditandai dengan tingkat mobilitas yang tinggi dan tidak dapat diprediksi (Srikanth \& Israel, 2012). Terdapat tiga hal besar yang dicatat sebagai perubahan dalam teori karier selama dua atau tiga dekade terakhir, yaitu perubahan dari karier organisasi menjadi karier protean, perubahan dari karier tunggal menjadi karier yang bersifat jamak (multiple) serta perubahan makna kesuksesan karier dari yang objektif menjadi subjektif (Hall, 2002). Kesuksesan dengan demikian merupakan hasil akhir dalam karier individu. Perubahan makna kesuksesan karier ini yang menjadikan penting untuk diteliti lebih mendalam dalam konteks masyarakat Indonesia.

Era gig economy mendorong semakin berkembangnya konsep independent worker yang ditandai dengan tingginya tingkat otonomi individu dalam pekerjaan, pembayaran berdasarkan penugasan serta hubungan pekerja dan pelanggan yang berlangsung dalam jangka waktu yang singkat. Para pekerja independen memiliki kontrol dan fleksibilitas tinggi dalam menentukan beban kerja dan portofolio pekerjaan, serta dapat mengubah pilihan kerjanya setiap waktu. Pembayaran diperoleh berdasarkan tugas yang dikerjakan atau volume penjualan, sehingga tidak seperti pekerja yang selalu mendapat gaji, pekerja independen tidak menerima bayaran pada waktu tidak bekerja. Umumnya jangka waktu pekerja independen adalah 12 bulan namun dapat diperpanjang dengan perjanjian / kontrak kerja baru. Jenis pekerjaan sebagai pekerja independen beragam dari pengendara antar jemput, desainer website, penasehat hukum, dan lain-lain. Terdapat tiga kategori pekerja independen yaitu: penyedia jasa, penjual produk/ layanan, layanan penyewaan aset (misalnya mengontrakkan kamar atau bangunan) (McKinsey Global Institute, 2016).

Perkembangan pekerja independen sejalan dengan konsep protean karier yang pertama kali dicetuskan oleh Dauglass $\mathrm{T}$ Hall pada tahun 1976. Protean karier merupakan orientasi kesuksesan karier yang lebih ditentukan oleh individu daripada organisasi, di mana kriteria kesuksesan karier dimaknai lebih subjektif berupa kesuksesan psikologis (Hall, 2004). Pada lingkungan bisnis saat ini di mana banyak terjadi skandal etika dalam organisasi dibutuhkan individu yang lebih protean. Individu sebagai penentu utama akan bertanggung jawab terhadap kariernya sehingga akan bertindak sesuai nilai yang dimilikinya, mampu melakukan refleksi diri (self reflective), personal audit, dan menjadi lebih jujur (Hall, 2004).

Konsep kesuksesan karier bagi sebagian besar orang masih dipahami dan sering dikaitkan dengan kesempatan memperoleh promosi, posisi dalam hierarki jabatan, peringkat (rank) dan retensi (Hall \& Chandler, 2005; Judge, Cable, Boudreau, \& Bretz, 1995). Kondisi ini menggambarkan fenomena dari perspektif kesuksesan karier objektif yang diukur berdasarkan gaji, peningkatan pendapatan, status, promosi dan capaian lain yang secara langsung dapat diukur dan diverifikasi (Abele \& Spurk 2009a, b; Heslin, 2005; Ng, Eby, Sorenson, \& Feldman, 2005; Judge et al., 1995). Keberhasilan karier yang objektif, seperti promosi dan kenaikan gaji, sering kali tidak tersedia untuk semua orang di orga- 
nisasi, terutama karena organisasi menjadi lebih datar dan karier menjadi kurang hierarkis dan tidak dapat diprediksi. Indikator kesuksesan karier ditandai secara objektif karena dapat diukur dan dinilai oleh orang lain, misalnya melalui catatan kerja atau bertanya pada karyawan (Lippe, 2011; Dette, Abele, \& Renner, 2004). Terhambatnya capaian objektif dalam karier dapat menimbulkan kekecewaan, frustrasi, penurunan kinerja, keterasingan pribadi dan pekerjaan, serta reaksi depresi (Hall, 2002; Korman, WittigBerman, \& Lang, 1981; Schein, 1978).

Perubahan kondisi eksternal berdampak pada kondisi internal organisasi dan berpengaruh terhadap perubahan model karier. Model pengembangan karier tradisional menjadi model pengembangan karier tanpa batas (no boundaries career development model) (Dai \& Song, 2016). Model pengembangan karier tradisional, umumnya terjadi pada organisasi yang berada pada lingkungan internal dan eksternal yang stabil, sehingga organisasi dapat menyediakan karier yang stabil dan permanen pada karyawan. Keberhasilan karier yang objektif, seperti promosi dan kenaikan gaji, sering kali tidak tersedia untuk semua orang di organisasi, terutama karena organisasi menjadi lebih datar dan karier menjadi kurang hierarkis dan tidak dapat diprediksi. Pada lingkungan organisasi yang berubah dengan cepat, model pengembangan karier tanpa batas memberikan peluang pengembangan karier karyawan berada di luar satu organisasi, karyawan menghadapi lebih banyak pilihan pengembangan. Fenomena maraknya karyawan alih daya (outsourcing), beralihnya pekerjaan para karyawan, profesional, bahkan manajer untuk mengembangkan wirausaha atau berkarier sebagai konsultan merupakan beberapa praktik model pengembangan karier tanpa batas (Defillippi \& Arthur, 2006).

Bergesernya makna kesuksesan karier terkait dengan terbatasnya ruang lingkup konsep kesuksesan karier objektif dalam mencakup keseluruhan makna kesuksesan dalam karier individu. Kriteria objektif dari kesuksesan karier terkontaminasi oleh pengaruh faktor-faktor yang berada di luar kendali individu. Misalnya berbagai kebijakan pemerintah tentang pajak, masa pensiun, aturan ketenagakerjaan dan lainlain berpengaruh terhadap gaji, fasilitas, posisi maupun aturan tentang promosi dan jenjang karier. Selain itu kesuksesan karier objektif juga memiliki defisiensi, karena apa yang dicari oleh individu dalam kariernya tidak hanya terbatas pada gaji, fasilitas, posisi atau jabatan struktural. Banyak pekerja merasakan kesuksesannya berdasarkan kriteria subjektif yang mereka miliki, misalnya para guru/ dosen yang menilai kesuksesannya berdasarkan banyaknya murid/mahasiswa yang sukses dalam kehidupannya. Dokter yang merasa sukses melihat para pasiennya yang sembuh dan menjadi lebih sehat, petugas perawat tanaman di taman kota yang merasa sukses saat menyaksikan tanamannya tumbuh subur dan indah serta banyak contoh lainnya. Saat ini semakin banyak yang memaknai kesuksesan kariernya berdasarkan hal yang less tangible, misalnya lebih mengutamakan keseimbangan kerja dengan kehidupan (work life balance), perasaan bermakna (sense of meaning), tujuan (purpose), trancendence serta kontribusi dari pekerjaannya (Heslin, 2005). 
Paparan di atas menunjukkan bahwa perubahan model karier berpengaruh terhadap pemaknaan tentang kesuksesan karier pada setiap individu. Selain kesuksesan karier objektif, berkembang perspektif lain dalam menilai kesuksesan karier, yaitu kesuksesan karier subjektif di mana pengalaman karier lebih dievaluasi dan dimaknai oleh individu yang bersangkutan (Heslin 2005; Abele, Spurk, \& Volmer, 2011). Dengan kata lain, individu dapat memiliki perspektif yang berbeda dalam menilai dan memaknai kesuksesan kariernya, hal ini biasanya dioperasionalkan dalam istilah kepuasan kerja atau kepuasan karier (Heslin, 2005).

Para peneliti secara empiris menemukan data bahwa persentase karyawan yang menilai kesuksesan kariernya berdasarkan indikator subjektif lebih besar daripada mereka yang menggunakan perspektif objektif (Eith, Stummer, \& Schusterschitz, 2011; Littler, Wiesner, \& Dunford, 2003; Sturges, Guest, Conway, \& Davey, 2002). Terutama pada organisasi yang mengembangkan model karier tanpa batas, kesuksesan karier subjektif menjadi lebih penting bagi individu (Defillippi \& Arthur, 2006). Dengan demikian, fenomena rasa frustrasi, penurunan kinerja, keterasingan pribadi dan pekerjaan, serta reaksi depresi yang muncul sebagai dampak negatif dari terhambatnya pencapaian kesuksesan karier objektif tidak dialami oleh mereka yang memiliki makna penilaian karier subjektif yang positif.

Terdapat keterkaitan yang kuat antara kesuksesan karier subjektif dan objektif (Abele \& Spurk, 2009; Ng et al., 2005). Kesuksesan karier subjektif memiliki pengaruh yang lebih luas dan lama dibandingkan kesuksesan karier objektif.
Kesuksesan karier subjektif memiliki pengaruh kuat terhadap kesuksesan karier objektif individu dari waktu ke waktu. Hal ini didasarkan bahwa kesuksesan karier subjektif akan memengaruhi kepercayaan diri dan meningkatkan motivasi dan usaha yang dikeluarkan individu sehingga pengalaman positif ini akan meluaskan sudut pandang individu dan membangun sumber dayanya sendiri (Diener, Nickerson, Lucas, \& Sandvick, 2002). Pada fase awal karier, kesuksesan karier objektif menjadi pendorong bagi kesuksesan karier subjektif terutama yang menggunakan referensi lain (membandingkan dengan orang lain yang menjadi kelompok referensi). Hal ini dikarenakan ketika berada di fase awal individu masih memiliki sedikit kriteria untuk mengevaluasi kesuksesan karier subjektif mereka.

Penelusuran literatur yang penulis lakukan menunjukkan bahwa kesuksesan karier subjektif memberikan dampak yang lebih positif bagi organisasi dan individu. Kesuksesan karier subjektif menjadi tujuan hidup utama individu (Herrmann, Hirschi, \& Baruch, 2015). Hasil penelitian terdahulu menunjukkan bahwa kesuksesan karier subjektif berkontribusi terhadap produktivitas organisasi dan emosi organisasi (Pachulicz, Schmitt, \& Kuljanin, 2008) seperti komitmen organisasi (Rasdi, Ismail, \& Garavan, 2011), kepuasan hidup dan kebahagiaan (Abele \& Spurk, 2009a,b); sikap para karyawan senior untuk tetap berada dalam organisasi (ArmstrongStassen \& Ursel, 2009) serta sikap kerja (Dyke \& Duxburry, 2011). Temuan sebelumnya seperti yang disebutkan di atas menunjukkan pentingnya organisasi untuk berusaha memahami bagaimana perasaan karyawan tentang kesuksesan 
karier subjektif mereka dan apa yang memengaruhinya. Penulis dalam artikel ini berusaha meninjau konsep dan konstruksi kesuksesan karier subjektif karyawan, dimulai dengan meninjau konsep kesuksesan karier subjektif dari masa ke masa, definisi, faktor-faktor yang memengaruhi, dampak, serta peran identitas karier pada kesuksesan karier subjektif.

\section{Pembahasan}

Kesuksesan Karier Subjektif dari Masa ke Masa

Pada awal tahun 1960-an, para peneliti mulai mengobservasi dampak dari perubahan lingkungan terhadap karier indivi$\mathrm{du}$ dalam suatu organisasi. Semakin dinamis dan kompleks suatu lingkungan, semakin "organik" dan semakin berbeda kebutuhan yang diperlukan untuk mencapai kesuksesan. Hasil observasi tersebut memunculkan konsep terkait "selfdesigning organization" yang dinilai lebih cocok dengan lingkungan yang selalu berubah-ubah. Self-designing organization tersebut bergantung pada keinginan individu untuk belajar dan eksplorasi kemampuan individu dalam meninjau pengalaman mereka. Pada self-designing organizations, eksternal karier seperti gelar, kenaikan jabatan dalam hierarki, dan jalur karier yang stabil terbilang jarang (Weick \& Berlinger, 1989). Oleh karena itu, individu perlu untuk fokus terhadap karier subjektif mereka dalam mencapai pertumbuhan karier. Individu perlu untuk berfokus pada proses dibandingkan hasil, kompetensi dibandingkan gelar, pemenuhan dibandingkan kenaikan, dan peran dibandingkan posisi.

Pada tahun 1990-an, pasar terbuka dan teknologi mendorong organisasi lebih berfokus pada kemampuan intelektual dibandingkan pada input fisik atau sumber daya natural. Hal tersebut memunculkan ide terkait organisasi tanpa batas (boundaryless organization) (Ashkenas, Ulrich, Jick, \& Kerr, 1995) di mana individu melakukan banyak pekerjaan, selalu mempelajari keterampilan baru, dan sering berpindah pada tugas baru serta lokasi yang berbeda. Organisasi menjadi lebih tidak terstruktur dan membuat individu lebih bergantung pada aspek internal seperti pertumbuhan, pembelajaran, dan integrasi. Individu bertindak sebagai agen perkembangan diri mereka sendiri dan mengorganisir secara kooperatif untuk belajar (Weick, 1996).

Penelitian terkait kesuksesan karier subjektif menjadi penting karena model karier telah berubah karena adanya pengaruh dari postmodernism. Terlihat bahwa kesuksesan telah bertransisi dari model pengembangan karier tradisional menjadi sebuah model pengembangan karier tanpa batas (Defillippi \& Arthur, 2006). Pada model pengembangan karier tradisional, lingkungan internal dan eksternal dari sebuah organisasi bersifat relatif stabil. Organisasi memberikan karier yang tetap dan stabil pada karyawan. Sebaliknya, pada model pengembangan karier tanpa batas, peluang perkembangan karyawan tidak hanya berasa dari satu organisasi, karyawan dihadapkan pada beberapa seleksi dan stabilitas kerja yang rendah. Perubahan dalam konteks karier tersebut membuat individu tidak bisa bergantung pada organisasi saja untuk mengembangkan kariernya (Hall \& Chandler, 2005; Hall \& Mirvis, 1995). Oleh karena itu individu diharapkan memiliki kemampuan untuk mengelola kariernya sendiri. 
Konsep kesuksesan karier saat ini lebih luas meliputi faktor objektif maupun subjektif. Definisi kesuksesan karier telah melibatkan persepsi individu terhadap kesuksesan kariernya yang terkadang tidak paralel dengan pengukuran sukses secara objektif (Hall, 1976). Gattiker dan Larwood (1988) menyatakan bahwa kesuksesan karier subjektif merupakan suatu konstruk yang muncul pada pemikiran individu dan tidak memiliki batasan. Sebagai contoh, Korman et al. (1981) menemukan bahwa manajer yang secara objektif sukses sering merasa tidak puas dengan kariernya dan tidak merasakan kesuksesan atau rasa bangga terhadap pencapaiannya. Hal tersebut dikarenakan perspektif mereka terhadap kesuksesan, mereka sering memandang diri mereka sendiri gagal. Ketika individu memiliki pandangan yang positif terhadap kariernya, maka ia cenderung memiliki pandangan yang positif pula terhadap kesuksesan kariernya. Pandangan/perspektif merupakan komponen subjektif pada individu.

\section{Definisi Kesuksesan Karier Subjektif}

Kesuksesan karier subjektif telah diidentifikasikan sebagai suatu konstruk yang penting sejak 50 tahun yang lalu oleh Hughes (1958). Ia menyatakan bahwa kesuksesan karier meliputi kriteria objektif dan subjektif. Hal tersebut menunjukkan bahwa konsep kesuksesan karier tidak dapat terlepas dari faktor objektif maupun subjektif. Definisi kesuksesan karier seharusnya juga melibatkan persepsi individu terhadap kesuksesan kariernya di mana hal tersebut tidak paralel dengan pengukuran objektif (Hall, 1976).
Individu mempunyai cara yang berbeda untuk menentukan kesuksesan karier subjektif. Pertama, individu membandingkan kesuksesannya saat ini dengan standar personal mereka seperti aspirasi personal, pencapaian di masa lalu, dan tujuan serta ekspektasi masa depan (Abele \& Spurk, 2009; Greenhaus, Parasuraman, \& Wormley, 1990). Individu akan membandingkan pencapaian mereka dengan tujuan karier mereka (Greenhaus et al., 1990), mereka tidak hanya memperhatikan tujuan yang telah dicapai tetapi juga tujuan yang belum tercapai maupun tujuan yang tidak akan tercapai (Korman et al., 1981). Kedua, individu menilai kesuksesan karier mereka berdasarkan standar eksternal seperti pencapaian dari rekan kerja, supervisor, mentor, ataupun anggota keluarga (Clark \& Arnold, 2008). Berdasarkan teori perbandingan sosial (Festinger, 1954), individu memiliki kecenderungan untuk membandingkan diri mereka dengan orang lain. Setiap individu mempunyai perspektif berbeda untuk menilai kesuksesan karier sehingga makna dari kesuksesan dapat bervariasi.

Kesuksesan karier subjektif memiliki berbagai definisi. Definisi tersebut tercantum pada Tabel 1. Beberapa definisi di atas menunjukkan bahwa kesuksesan karier subjektif berfokus pada individu dan dapat diinterpretasikan menjadi dua makna. Pertama, individu melakukan evaluasi subjektif pada kesuksesan karier mereka secara keseluruhan dan tidak berkaitan dengan faktor objektif. Kedua, terdapat komponen tambahan pada kesuksesan karier selain faktor objektif. (misal, tidak dapat diperoleh hanya dengan melihat database organisasi). 
Tabel 1.

Definisi Kesuksesan Karier Subjektif

\begin{tabular}{|c|c|c|}
\hline No. & Definisi Kesuksesan Karier Subjektif & Tokoh \\
\hline 1. & $\begin{array}{l}\text { Kesuksesan karier subjektif meliputi realisasi tujuan, identitas } \\
\text { diri, dan peluang yang dipersepsi untuk promosi. }\end{array}$ & Heslin (2005) \\
\hline 2. & $\begin{array}{l}\text { Kesuksesan karier subjektif didefinisikan sebagai evaluasi diri } \\
\text { terhadap perkembangan karier }\end{array}$ & $\begin{array}{l}\text { Arthur, Khapova, dan } \\
\text { Wilderom. (2005) }\end{array}$ \\
\hline 3. & $\begin{array}{l}\text { Kesuksesan karier subjektif adalah evaluasi perseptual } \\
\text { individu serta reaksi afektif terhadap kariernya. }\end{array}$ & Ng dan Feldman (2014) \\
\hline 4. & $\begin{array}{l}\text { Kesuksesan karier subjektif mengambarkan pemahaman dan } \\
\text { evaluasi individu terhadap kariernya }\end{array}$ & $\begin{array}{l}\text { Gattiker dan Larwood } \\
\text { (1986) Parker dan Arthur } \\
\text { (2002); Van Maanen (1977) }\end{array}$ \\
\hline 5. & $\begin{array}{l}\text { Kesuksesan karier subjektif ditunjukkan oleh reaksi individu } \\
\text { terhadap pengalaman kariernya }\end{array}$ & Hughes (1958) \\
\hline 6. & $\begin{array}{l}\text { Kesuksesan karier subjektif menunjukkan persepsi individu } \\
\text { terhadap pencapaian, perspektif masa depan, rekognisi, dan } \\
\text { kepuasan karier. }\end{array}$ & Nabi (1999) \\
\hline 7. & $\begin{array}{l}\text { Kesuksesan karier subjektif merupakan penilaian individu } \\
\text { terhadap pengalaman karier mereka dan akumulasi dari } \\
\text { pencapaian yang dirasakan individu sebagai sebuah hasil dari } \\
\text { pengalaman kerja mereka }\end{array}$ & $\begin{array}{l}\text { Judge, Higgins, Thoresen, } \\
\text { dan Barrick (1999) }\end{array}$ \\
\hline
\end{tabular}

Kesuksesan karier subjektif juga dapat dinilai dan dimaknai berdasarkan emosi dan kognisi (See, Petty, \& Fabrigar, 2008). Penilaian dan pemaknaan kesuksesan karier subjektif yang berdasarkan emosi mengacu pada perasaan, reaksi emosi, dan kepuasan karyawan terhadap kesuksesan kariernya (Nicholson \& De WaalAndrews, 2005). Penilaian dan pemaknaan kesuksesan karier subjektif yang berdasarkan kognisi di sisi lain lebih mengacu pada keyakinan dan persepsi individu terhadap kesuksesan kariernya.

Kesuksesan karier juga berkaitan dengan hasil dan pencapaian yang bersifat akumulatif sepanjang pengalaman kerja seseorang (Seibert \& Kraimer, 2001). Kajian literatur menunjukkan bahwa kesuksesan karier memiliki sifat dikotomi, menunjukkan dimensi objektif dan subjektif (Arthur, Khapova, \& Wilderom, 2005; Mulhall, 2011). Dimensi-dimensi tersebut meski secara empiris ditemukan berkorelasi positif, namun secara empiris juga ditemukan berbeda (Abele \& Spurk, 2009). Keberhasilan karier subjektif sangat berkaitan dengan pemahaman tentang karier sebagai "rangkaian pengalaman kerja yang berkembang dari waktu ke waktu" (Arthur, Hall, \& Lawrence, 1989) dan menyiratkan penilaian / evaluasi subjektif individu (Abele \& Spurk, 2009; Dries, Pepermans, \& Carlier, 2008; Ng et al. 2005). Pengertian keberhasilan subjektif dalam hal ini meliputi kepuasan kerja, keseimbangan kerja dan kehidupan, peningkatan diri, dan orientasi kerja yang merupakan unsur intrinsik dari perilaku kerja individu (Heslin, 2005).

\section{Faktor-Faktor yang Memengaruhi}

Tingkat kepuasan karier subjektif setiap individu akan berbeda-beda dikarenakan oleh berbagai faktor baik pada konteks 
individu maupun pada konteks organisasi. Pada konteks individu, faktor demografis seperti jenis kelamin, status perkawinan, usia, dan kelompok bahasa (Judge et al., 1995; Ng et al., 2005; Park, 2010) diketahui dapat berpengaruh terhadap kesuksesan karier subjektif. Faktor demografis meski demikian secara empiris terbukti tidak menunjukkan pengaruh yang cukup besar terhadap kesuksesan karier subjektif. Faktor demografis cenderung memiliki pengaruh yang besar terhadap kesuksesan karier objektif (Ng et al., 2005).

Tipe kepribadian proaktif dianggap dianggap menjadi salah satu indikator dari kesuksesan karier subjektif ( $\mathrm{Ng}$ et al., 2005; Spurk, Volmer, Hagmaier, \& Kauffeld, 2013). Individu yang proaktif cenderung mencari peluang yang baru dan berbeda, menunjukkan inisiatif, dan tekun untuk membawa perubahan yang bermakna (Bateman \& Crant, 1999). Kepribadian proaktif ini harus dimiliki individu dalam era organisasi tanpa batas saat ini jika mereka ingin mencapai kesuksesan karier.

Pada konteks individu terkait pengetahuan dan keterampilan individu, diketahui juga memiliki dampak yang signifikan terhadap kesuksesan karier subjektif (Wang, 2012). Pengetahuan dan keterampilan yang dipelajari individu sebelumnya akan digunakan dalam proses kerja selama individu menjalani kariernya. Selanjutnya, kemampuan individu untuk beradaptasi dalam menjalani kariernya atau adaptabilitas karier juga merupakan salah satu prediktor penting pada kesuksesan karier subjektif (Zacher, 2014; Ibrahim \& Amari, 2018). Savickas (2005) menegaskan bahwa adaptasi yang berkelanjutan terhadap lingkungan kerja bersifat penting dalam pencapaian kesuksesan karier. Adaptabilitas karier menjadi sumber regulasi diri di mana individu akan mampu menyelesaikan permasalahan asing dan kompleks yang muncul dari tugas vokasional, transisi pekerjaan, dan trauma kerja (Savickas, 2002; Savickas \& Porfeli, 2012).

Selain kemampuan beradaptasi, $\mathrm{Ng}$ dan Feldman (2014) menyatakan bahwa rendahnya kesuksesan karier subjektif individu dapat dipengaruhi oleh persepsi dan reaksi individu terhadap pekerjaan mereka saat ini dan terhadap organisasi. Sebagian dari reaksi tersebut di antaranya adalah rendahnya evaluasi diri, ketidakpuasan terhadap pekerjaan, rendahnya komitmen organisasi, rendahnya komitmen pekerjaan, rendahnya keterikatan kerja, rendahnya dukungan supervisor secara umum, rendahnya dukungan supervisor yang berhubungan dengan karier, rendahnya peluang promosi, dan tidak tercapainya ekspektasi. Individu ketika menilai kesuksesan karier subjektif, tidak hanya mempertimbangkan tentang apa yang telah dicapai dalam karier tetapi juga mempertimbangkan hal tidak tercapai (Korman et al., 1981). Organanisasi oleh karena itu perlu mengetahui dan memahami tentang apa yang diharapkan oleh individu dalam kariernya (Heslin, 2005).

Kesuksesan karier dalam konteks organisasi sangat dipengaruhi oleh faktor keterlibatan kerja karyawan dalam organisasi. Faktor keterlibatan kerja karyawan juga dianggap sebagai prediktor yang kuat untuk kesuksesan karier subjektif (Nabi, 1999). Kemudian, organizational sponsorship seperti mentorship dan sumber daya organisasi juga diketahui memiliki dampak terhadap kesuksesan karier subjektif 
individu (Ng et al., 2005; Omondi, Obonyo, Muindi, \& Odock, 2019). Organizational sponsorship dapat membantu individu untuk mencapai kesuksesan karier subjektif. Hal tersebut menunjukkan bahwa kesuksesan karier subjektif juga dapat dipengaruhi oleh hubungan positif yang terjalin antara individu dengan supervisornya ( $\mathrm{Ng}$ et al., 2005). Ketika supervisor atau manajer tertarik dan menghargai hasil kerja seorang karyawan, maka ia akan cenderung merasakan kesuksesan di dalam kariernya (Koekemoer, Fourie, \& Jorgensen, 2018). Social network atau jaringan sosial (Rasdi et al., 2011) dan informal network (Emmerik, Euwema, Geschiere, \& Schouten, 2006) dapat menjadi faktor penting dalam kesuksesan karier subjektif.

\section{Dampak Kesuksesan Karier Subjektif}

Hasil penelitian terdahulu menunjukkan bahwa kesuksesan karier subjektif berkontribusi terhadap produktivitas organisasi dan emosi organisasi (Pachulicz et al., 2008) seperti komitmen organisasi. Selain itu, perasaan dari karyawan (Abele \& Spurk, 2009a) seperti kepuasan hidup dan kebahagiaan juga dipengaruhi oleh kesuksesan karier subjektif. Abele dan Spurk (2009b) juga menyatakan bahwa tingkat kesuksesan karier subjektif yang tinggi akan meningkatkan kepercayaan individu, motivasi kerja, dan kerja keras dalam mencapai tujuan di mana hal itu juga secara positif akan memengaruhi produktivitas individu di masa depan.

Lalu, kesuksesan karier subjektif juga merupakan keluaran dari komitmen karier (Ballout, 2009) karena komitmen karier mampu memprediksi kesuksesan karier subjektif pada individu (Karavardar, 2014;
Srikanth \& Israel, 2012). Individu yang memiliki tingkat komitmen karier yang tinggi akan cenderung memiliki tingkat kesuksesan karier subjektif yang tinggi pula.

Peran Identitas Karier pada Kesuksesan Karier Subjektif

Identitas karier mewakili bagaimana individu mendefinisikan diri mereka dalam konteks karier. Bertindak sebagai "kompas kognitif", identitas karier membantu individu dalam mewujudkan, menciptakan, dan menggunakan peluang (Fugate, Kinicki, \& Ashforth, 2004). Identitas karier bersifat longitudinal, karena itu membuat pengalaman di masa lalu seseorang menjadi masuk akal, dan memberikan arah masa depan. Ini tidak terkait dengan jumlah pengalaman kerja di masa lalu tetapi penggabungan pengalaman-pengalaman menjadi struktur yang bermakna dan berguna (Fugate et al., 2004). Istilah karier dapat dipertukarkan dengan istilah identitas vokasi yang mengacu pada persepsi-diri yang dimiliki seseorang selama perkembangan karier mereka tentang keterampilan, kemampuan, dan kebutuhan kerja jangka panjang (Feldman \& Thomas, 2007). Identitas karier adalah salah satu dimensi dari konsep kerja (McArdle, Waters, Briscoe, \& Hall, 2007). Identitas vokasi didefinisikan sebagai "... kepemilikan dari gambaran yang jelas dan stabil tentang tujuan, minat, dan bakat seseorang" (Holland, Gottfredosn, \& Power, 1980). McArdle et al. (2007) juga mendefinisikan identitas karier sebagai: Kemampuan untuk mendapatkan dan mempertahankan pekerjaan, baik di dalam dan di seluruh organisasi. 
Lippe (2011) menyatakan bahwa motivasi karier merupakan hal yang menentukan pilihan perspektif individu dalam menilai kesuksesan kariernya. Motivasi karier merupakan motivasi individu dalam melaksanakan pekerjaannya yang menjadi kekuatan pendorong dibalik keputusan dan perilaku individu di dalam kariernya (Lippe, 2011). Aspek yang terpenting dalam motivasi karier adalah identitas karier yang merepresentasikan seberapa penting makna karier bagi identitas individu dan bagaimana individu mendefinisikan dirinya dalam pekerjaan. Terdapat dua sub domain dalam identitas karier, yaitu keterlibatan kerja (work involvement) dan keinginan untuk bergerak ke atas (desire for upward mobility). Keterlibatan kerja merupakan gambaran profesional individu yang mengarahkan individu untuk bekerja keras, berkomitmen terhadap pekerjaan dan organisasi. Keinginan untuk bergerak ke atas merupakan kebutuhan individu untuk berprestasi, memperoleh penghargaan, dominasi dan uang, menggambarkan individu yang mendaki tangga karier (Lippe, 2011).

Menurut Lippe (2011) perbedaan dominasi dan dinamika antara keterlibatan kerja dan keinginan untuk bergerak ke atas inilah yang memengaruhi individu dalam memilih perspektif dalam menilai kesuksesan kariernya. Beberapa bukti empiris juga menunjukkan hubungan positif antara keterlibatan kerja dan kesuksesan karier subjektif. Nabi (1999) menemukan bahwa keterlibatan kerja karyawan merupakan prediktor kuat untuk keberhasilan karier subjektif tetapi tidak untuk keberhasilan karier yang objektif. Aryee, Wyatt, dan Stone (1996) menemukan hasil serupa dalam studi mereka tentang hasil karier awal karyawan pascasarjana. Mereka mendeteksi hubungan positif antara identitas karier, yang mencerminkan pentingnya bekerja dalam kehidupan seorang karyawan dibandingkan dengan pentingnya domain kehidupan utama lainnya, dan kepuasan karier (yang sering digunakan sebagai ukuran keberhasilan karier subjektif). Namun, mereka tidak mendeteksi hubungan antara identitas karier, gaji dan jumlah promosi (sering digunakan sebagai ukuran keberhasilan karier objektif). Temuan ini menunjukkan bahwa individu dengan keterlibatan kerja yang kuat sangat terfokus pada pencapaian hasil karier subjektif.

\section{Penutup}

Kesuksesan karier subjektif menjadi hal yang sangat penting pada pengembangan karier karyawan terutama bagi Human Resources Management dalam organisasi saat ini. Organisasi tanpa batas, karier protean bahkan perubahan makna karier menjadi pemicu utama munculnya kesuksesan karier subjektif. Pengembangan penelitian dimulai dari melakukan eksplorasi terhadap kesuksesan karier subjektif pada sumber daya manusia di Indonesia dengan menggunakan pendekatan pengukuran budaya dari Hofstede maupun Globe. Pembentukan dan pengembangan model berdasarkan pendekatan teori tertentu seperti Career Construction Theory and Life Design untuk mendapatkan gambaran yang utuh mengenai kesuksesan karier subjektif. Identitas karier memiliki pengaruh yang sangat besar dalam memaknai kesuksesan karier pada individu dalam organisasi. 
Pemahaman tentang kesuksesan karier subjektif dalam konteks manajemen sumber daya manusia di Indonesia menjadi semakin penting karena peran dan pengaruh gig economy akan semakin besar dan penting bagi perekonomian nasional (Ali, 2018; Yahdi, 2018). Jumlah angkatan kerja di Indonesia dalam gig economy juga semakin besar. Data Badan Pusat Statistik per Mei 2019 mencatat jumlah pekerja lepas di Indonesia sebanyak 4,55 persen dari 129,36 juta pekerja di Indonesia. Angka persentase itu berarti angka pekerja lepas berjumlah sekitar 5,89 juta orang (Hadi, 2020).

Perilaku dan sikap kerja para pekerja gig sampai sejauh ini masih belum dipahami secara mendalam berkaitan dengan aspek perilaku dan sikap kerja mereka (Kuhn \& Galloway, 2019; Keegan \& Meijerink, 2019; Meijerink \& Keegan, 2019). Upaya mengkaji dan meneliti perilaku dan sikap kerja para pekerja gig tersebut penting untuk dilakukan karena karakteristik kepribadian, proses perkembangan individu, pengaruh teknologi, ekosistem kerja para pekerja gig berbeda dengan para pekerja yang lain (Kuhn \& Galloway, 2019). Upaya untuk lebih memahami karakteristik perilaku dan sikap kerja pekerja gig diharapkan dapat meningkatkan kemampuan organisasi dalam mengelola dan meningkatkan kinerja dan kualitas hidup pekerja gig.

\section{Daftar Pustaka}

Abele, A. E., Spurk, D., \& Volmer, J. (2011). The construct of career success: Measurement issues and an empirical example. Zeitschrift für Arbeitsmarktforschung, 43, 195-206.
Abele, A. E. \& Spurk, D. (2009a). The longitudinal impact of self-efficacy and career goals on objective and subjective career success. Journal of Vocational Behavior, 74, 53-62. doi: 10.1016/j.jvb.2008.10.005

Abele, A. E., \& Spurk, D. (2009b). How do objective and subjective career success interrelate over time? Journal Occupational Organizational Psychology, 82, 803-824. doi: 10.1348/096317909X470924

Ali, L. M. (2018). Milenial dan "gig economy" di era industri 4.0. Kompas.com, 15 November 2018.

Armstrong-Stassen, D. M. \& Ursel, N. D. (2009). Perceived organizational support, career satisfaction, and the retention of older workers. Journal of Occupational \& Organizational Psychology, 82, 201-220. doi: $\underline{10.1348 / 096317908 \times 288838}$

Arthur, M. B., Hall, D. T., \& Lawrence, B. S. (1989). Handbook of career theory. New York: Cambridge University Press.

Arthur, M., Khapova, S., \& Wilderom, C. (2005). Career success in a boundary less career world. Journal of Organizational Behavior, 26, 177-202. doi: $\underline{10.1002 / j o b .290}$

Aryee, S., Wyatt, T., \& Stone, R. (1996). Early career outcomes of graduate employees: The effect of mentoring and ingratiation. Journal of Management Studies, 33, 95-118. doi: 10.1111/j.14676486.1996.tb00800.x

Ashkenas, R., Ulrich, D., Jick, T., \& Kerr, S. (1995). The boundaryless organization: Breaking the chains of organizational structure. San Francisco: Jossey-Bass.

Ballout, H.I. (2009). Career commitment and career success: Moderating role of self-efficacy. Career Development 
International, 14(7), 655-670. doi: $\underline{10.1108 / 13620430911005708}$

Bateman, T.S., \& Crant, J.M. (1999). Proactive behavior: Meaning, impact, recommendations. Business Horizons, 42(3), 63-70.

Clark, M. \& Arnold, J. (2008). The nature, prevalence and correlates of generativity among men in middle career. Journal of Vocational Behavior, 73, 473484.

Dai, L. T. \& Song, F. H. (2016) Subjective career success: A Literature review and prospect. Journal of Human Resource and Sustainability Studies, 4, 238-242. doi: 10.4236/jhrss.2016.43026

Fieldman., D. C. \& Thomas, W. H. Ng. (2007). Careers: mobility, embeddeness and succes. Journal of Management, 33, 350-377. doi: $\underline{10.1177 / 0149206307300815}$

Defillippi, R.J. \& Arthur, M.B. (2006) The boundary less career: A competencybased perspective. Journal of Organizational Behavior, 15, 307-324. doi: $\underline{\text { 10.1002/job.4030150403 }}$

Dette, E. D., Abele, A. E., \& Renner, O. (2004). Zur Definition und Messung von Berufserfolg - theoretische U* berlegungen und metaanalytische Befunde zum Zusammenhang von externen und internen Laufbahnerfolgsmaßen [Definition and measurement of career successTheoretical considerations and metaanalytical findings on the relationship between external and internal career measures]. Zeitschrift für Personalpsychologie, 3, 170-183. doi: $\underline{10.1026 / 1617-6391.3 .4 .170}$

Diener, E., Nickerson, C., Lucas, R. E., \& Sandvik, E. (2002). Dispositional affect and job outcomes. Social Indicators Research, 59, 229-259.
Dries, N., Pepermans, R., \& Carlier, O. (2008). Career success: Constructing a multidimensional model. Journal of Vocational Behavior, 73, 254-267. doi: 10.1016/j.jvb.2008.05.005

Dyke, L. \& Duxburry, L. (2011). The implications of subjective career success. Springer, 43, 219-229.

Eith, T. K., Stummer, H., \& Schusterschitz, C. (2011). Career success perception and work-related behavior of employees in geriatric care - A pilot study in a German geriatric care facility. Scandinavian Journal of Caring Sciences, 25, 45-52. doi: 10.1111/j.14716712.2010.00789.x.

Emmerik, I. H. V., Euwema, M. C., Geschiere, M., \& Schouten, M. F. A. G. (2006). Networking your way through the organization: Gender differences in the relationship between network participation and career satisfaction. Women in Management Review, 21, 5466. doi: $10.1108 / 09649420610643411$

Festinger, L. (1954). A theory of social comparison processes. Human Relations, 7, 117-140. doi: $\underline{10.1177 / 001872675400700202}$

Fugate, M., Kinicki, A. J., \& Ashforth, B. E. (2004). Employability: A psycho-social construct, its dimensions, and applications. Journal of Vocational Behavior, 65, 14-38. doi: 10.1016/j.jvb.2003.10.005

Gattiker, U., \& Larwood, L. (1986). Subjective career success: A study of managers and support personnel. Journal of Business and Psychology, 1(2), 78-94.

Greenhaus, J., Parasuraman, S., \& Wormley, W. (1990). Effects of race on organizational experiences, job performance evaluations, and career outcomes. The Academy of Management Journal, 33, 64-86. 
Hadi, A. (2020). Mengenal 'Gig Economy': Dunia kerja baru yang rentan eksploitasi. Tirto.id, 4 Januari 2020.

Hall, D. (1996). Protean Careers of the 21st Century. The Academy of Management Executive (1993-2005), 10(4), 8-16. Diunduh dari www.jstor.org/stable/4165349, 2 Maret 2020

Hall, D. T. (1976). Careers in organizations. Pacific Palisades, CA: Goodyear.

Hall, D. T. (2002). Careers in and out of organizations. Thousand Oaks, CA: Sage.

Hall, D. T. (2004). The protean career: A quarter-century journey. Journal of Vocational Behavior, 65(1), 1-13. doi: 10.1016/j.jvb.2003.10.006

Hall, D. T. et al. (1996). The career is deadlong live the career: A relational approach to careers. San Francisco. CA: JosseyBass.

Hall, D. T., \& Chandler, D. E. (2005). Psychological success: When the career is a calling. Journal of Organizational Behavior, 26, 155-176. doi: $10.1002 / j o b .301$

Hall, D. T., \& Mirvis, P. H. (1995). The new career contract: Developing the whole person at midlife and beyond. Journal of Vocational Behavior, 47, 269-289. doi: 10.1006/jvbe.1995.0004

Herrmann, A., Hirschi, A., \& Baruch, Y. (2015). The protean career orientation as predictor of career outcomes: Evaluation of incremental validity and mediation effects. Journal of Vocational Behavior, 88, 205-214. doi:

10.1016/j.jvb.2015.03.008

Heslin, P. (2005). Conceptualizing and evaluating career success. Journal of Organizational Behavior, 26, 113-136. doi: $10.1002 / j o b .270$
Holland, J. J., Gottfredosn, D. C., \& Power, P. G. (1980). Some diagnostic scales for research in decision making and personality: Identity, information, and barriers. Journal of Personality and Social Psychology, 39(6), 1191. doi: $\underline{10.1037 / \mathrm{h} 0077731}$

Hughes, E. (1958). Men and their work. Glencoe, IL: Free Press.

Ibrahim, M. M. S. \& Amari, A. A. (2018). Influence of the psychological capital and perceived organizational support on subjective career success: The mediating role of women's career adaptability in the Saudi context. International Journal of Business and Management, 13(9), 189-207. doi: 10.5539/ijbm.v13n9p189

Judge, T. A., Cable, D. M., Boudreau, J. W., \& Bretz, R. D. (1995). An empirical investigation of the predictors of executive career success. Personnel Psychology, 48, 485-519. doi: 10.1111/j.1744-6570.1995.tb01767.x

Judge, T. A., Higgins, C. A., Thoresen, C. J., \& Barrick, M. R. (1999). The big five personality traits, general mental ability, and career success across the life span. Personnel Psychology, 52, 621652. doi: 10.1111/j.1744-

Karavardar, G. (2014). Career commitment, subjective career success and career satisfaction in the context of hazelnut processing industry in Giresun/Turkey. International Journal of Business and Management, 9(6). doi: 10.5539/ijbm.v9n6p98

Keegan, A. E., \& Meijerink, J. (2019). Conceptualizing human resource management in the gig economy: Toward a platform ecosystem perspective. Journal of Managerial Psychology, 34(4), 214-232. 
Koekemoer, E., Fourie, H. L. R., \& Jorgensen, L. I. (2018). Exploring subjective career success among bluecollar workers: Motivators that matter. Journal of Career Development, 1-18. doi: $\underline{10.1177 / 0894845318763942}$

Korman, A., Wittig-Berman, U., \& Lang, D. (1981). Career success and personal failure: Alienation in professionals and managers. Academy of Management Journal, 24, 342-360. doi: $\underline{10.2307 / 255846}$

Kuhn, K. M., \& Galloway, T. L. (2019). Expanding perspectives on gig work and gig workers. Journal of Managerial Psychology, 34(4), 186-191.

Lippe, L. (2011). What leads individuals to take a subjective or an objective perspective to evaluate career success? Bachelor Thesis. Belanda: University of Twente.

Littler, C. R., Wiesner, R., \& Dunford, R. (2003). The dynamics of delayering: Changing management structures in three countries. Journal of Management Studies, 40, 225-256. doi: 10.1111/1467$\underline{6486.00339}$

McArdle, S., Waters, L., Briscoe, J. P., \& Hall, D. T. (2007). Employability during unemployment: Adaptability, career identity and human and social capital. Journal of Vocational Behavior, 71, 247-264. doi: 10.1016/j.jvb.2007.06.003

McKinsey Global Institute. (2016). Independent work: choice, necessity, and the gig economy. Research Report, October, 1-133.

Meijerink, J., \& Keegan, A. (2019). Conceptualizing human resource management in the gig economy. Journal of Managerial Psychology, 34(4), 214-232.
Mulhall, S. (2011). CSI: Career Success Investigation. Irish Journal of Management, 67-93.

Nabi, G. R. (1999). An investigation into the differential profile of predictors of objective and subjective career success. Career Development International, 4, 212-224. doi: $\underline{10.1108 / 13620439910270599}$

Ng, T. W. \& Feldman, D. C. (2014). Subjective career success: A metaanalytic review. Journal of Vocational Behavior, 85(2), 169-179. doi: 10.1016/j.jvb.2014.06.001

Ng, T., Eby, L., Sorenson, K., \& Feldman, D. (2005). Predictors of objective and subjective career success. Personnel Psychology, 58, 367-408. doi: 10.1111/j.1744-6570.2005.00515.x

Nicholson, N. \& De Waal-Andrews, W. (2005). Playing to win: Biological imperatives, self-regulation, and tradeoffs in the game of career success. Journal of Organizational Behavior, 26, 137-154. doi: 10.1002/job.295

Omondi, A. A., Obonyo, P. K., Muindi, F., \& Odock, S. (2019). Examining the effect of organizational sponsorship on subjective career success of managerial staff in large manufacturing firms in Kenya. European Journal of Scientific Research, 152(3), 225-235.

Pachulicz, S., Schmitt, N., \& Kuljanin, G. (2008). A model of career success: A longitudinal study of emergency physicians. Journal of Vocational Behavior, 73, 242-253. doi: 10.1016/j.jvb.2008.05.003

Park, Y. (2010). The predictors of subjective career success: An empirical study of employee development in a Korean financial company. International Journal of Training and 
Development, $\quad 14, \quad 1-15 . \quad$ doi: 10.1111/j.1468-2419.2009.00337.x

Parker, P., \& Arthur, M. (2002). Bringing "new science" into careers research. Management, 5, 105-125.

Rasdi, R. M., Ismail, M., \& Garavan, T. N. (2011). Predicting Malaysian managers' objective and subjective career success. The International Journal of Human Resource Management, 1-22. doi: $10.1080 / 09585192.2011 .560878$

Savickas, M. L. (2002). Career construction: A developmental theory of vocational behavior. In D. Brown (Ed.), Career choice and development (4th ed., 149205). San Francisco, CA: Jossey-Bass.

Savickas, M. L. (2005). The theory and practice of career construction. In $\mathrm{R}$. W. Lent, \& S. D. Brown (Eds.), Career development and counseling: Putting theory and research to work (pp. 42-70). Hoboken, New Jersey: John Wiley \& Sons.

Savickas, M. L., \& Porfeli, E. J. (2012). Career Adapt-Abilities Scale: Construction, reliability, and measurement equivalence across 13 countries. Journal of Vocational Behavior, 80(3), 661-673. doi: 10.1016/j.jvb.2012.01.011

Schein, E. H. (1978). Career dynamics: Matching individual and organizational needs. Reading, MA: AddisonWesley

See, Y. H. M., Petty, R. E., \& Fabrigar, L. R. (2008). Affective and cognitive metabases of attitudes: Unique effects on information interest and persuasion. Journal of Personality and Social Psychology, 94, 938-955. doi: $\underline{10.1037 / 0022-3514.94 .6 .938}$

Seibert, S., Kraimer, M., \& Liden, R. (2001). A social capital theory of career success. Academy of Management
Journal, 44, 219-237. doi: $\underline{10.2307 / 3069452}$

Spurk, D., Volmer. J., Hagmaier, T., \& Kauffeld, S. (2013). Why are proactive people more successful in their careers? The role of career adaptability in explaining multiple career success criteria. In E. E. Crossman, \& M. A. Weiler (eds.), Personality Traits: Causes, Conceptions and Consequences. New York: Nova Publishers

Srikanth, P.B. \& Israel, D. (2012). Career commitment \& career success: Mediating role of career satisfaction. The Indian Journal of Industrial Relations, 48(1), 137-149.

Sturges, J., Guest, D., Conway, N., \& Davey, K. M. (2002). A longitudinal study of the relationship between career management and organizational commitment among graduates in the first ten years at work. Journal of Organizational Behavior, 23, 731-748. doi: 10.1002/job.164

Van Maanen, J. (1977). Introduction: The promise of career studies. In J. Van Maanen (Ed.), Organizational careers: Some new perspectives (pp. 1-12). London: Wiley.

Wang, F. (2012). The influence factors of IT industry knowledge-based employees' career success research. University of Inner Mongolia.

Weick, K. E. (1996). Enactment and the boundaryless career: Organizing as we work. In M. B. Arthur \& D. M. Rousseau (Eds.), The boundaryless career (pp. 40-57). New York: Oxford University Press.

Weick, K. E., \& Berlinger, L. (1989). Career improvisation in self-designing organizations. In M. B. Arthur, D. T. Hall, \& B. S. Lawrence (Eds.), 
Handbook of career theory (pp. 313-328). New York: Cambridge University Press.

Yahdi, P. I. (2018). Perlindungan kerja krusial di era gig economy. Bisnis.com, 14 November 2018.
Zacher, H. (2014). Career adaptability predicts subjective career success above and beyond personality traits and core self-evaluations. Journal of Vocational Behavior, 84, 21-30. doi: $\underline{10.1016 / j . j v b .2013 .10 .002}$ 